\title{
Distribusi, Retensi, dan Penetrasi Bahan Pengawet Ekstrak Daun Tuba (Derris elliptica Benth) pada Kayu Kemiri dan Kayu Agathis (Distribution, Retention, and Penetration of Tuba Leaves Extract (Derris elliptica Benth) on Aleurites moluccana and Agathis Wood)
}

\author{
Syahidah*, Andi Detti Yunianti \\ Laboratorium Pemanfaatan dan Pengolahan Hasil Hutan, Fakultas Kehutanan, \\ Universitas Hasanuddin Makassar, Sulawesi Selatan \\ *Penulis korespondensi: syahidah@unhas.ac.id
}

\begin{abstract}
Wood preservation is carried out to increase the service life of wood with low natural durability. Factors such as wood structure, preservatives, and methods of preservation influence the preservation processes. The aim of this study was to evaluate retention, penetration, and distribution of tuba (Derris elliptica) leaves extract into the candlenut wood (Aleurites molluccana) and agathis (Agathis sp.) wood structures. The wood samples were treated with hot and cold soaking. The duration of hot soaking were 3, 5, and 7 hours, while for cold soaking were 3,5 , and 7 days. The result showed that the highest retention of extract was achieved by cold soaking for 7 days at $9.4 \mathrm{~kg} \mathrm{~m}^{-3}$, and the lowest retention was achieved by hot soaking for 3 hours at $1.9 \mathrm{~kg} \mathrm{~m}^{-3}$. The highest penetration occured by cold soaking for 7 days at $8.08 \mathrm{~mm}$ and the lowest was that with hot soaking for 3 hours at $2.81 \mathrm{~mm}$. However, the distribution of the extract in the agathis wood structures could not be detected by stereo microscope. In the the case of the candlenut wood, the extract was distributed in the parenchyma cell.
\end{abstract}

Keywords: cold soaking, derris elliptica leave extract, distribution, hot soaking, penetration, retention

\begin{abstract}
Abstrak
Pengawetan kayu merupakan upaya untuk memperpanjang masa pakai kayu, khususnya untuk kayu yang memiliki daya tahan alami rendah. Proses pengawetan dipengaruhi oleh beberapa faktor seperti struktur kayu, pengawet, dan metode pengawetan. Tujuan dari penelitian ini adalah untuk mengevaluasi retensi, penetrasi, dan distribusi ekstrak daun tuba dalam struktur kayu kemiri dan agatis. Sampel kayu diberi perlakuan dengan perendaman panas dan dingin. Periode perendaman panas adalah 3 jam, 5 jam, dan 7 jam, sedangkan untuk perendaman dingin adalah 3 hari, 5 hari, dan 7 . Hasil penelitian menunjukkan bahwa retensi tertinggi diperoleh dengan perendaman dingin selama 7 hari sebesar $9,4 \mathrm{~kg} \mathrm{~m}^{-3}$, dan retensi terendah diperoleh dengan perendaman panas selama 3 jam sebesar $1,9 \mathrm{~kg} \mathrm{~m}^{-3}$. Penetrasi tertinggi dicapai dengan perendaman dingin selama 7 hari sebesar $8,08 \mathrm{~mm}$, sedangkan penetrasi terendah dicapai dengan perendaman panas selama 3 jam sebesar $2,81 \mathrm{~mm}$. Namun, distribusi ekstrak dalam struktur kayu agatis tidak dapat dideteksi menggunakan mikroskop stereo, sedangkan untuk kayu kemiri, ekstrak terdistribusi di dalam sel parenkim.
\end{abstract}

Kata kunci: distribusi, ekstrak daun tuba, penetrasi, perendaman dingin, perendaman panas, retensi 


\section{Pendahuluan}

Kayu merupakan bahan berlignoselulosa yang terdiri atas komponen polisakarida dan lignin, sehingga dapat diserang oleh organisme perusak. Serangan organisme perusak dapat memperpendek umur pakai kayu dan merugikan pengguna karena harus melakukan penggantian (Barly 2013). Salah satu cara memperpanjang umur pakai kayu adalah melalui proses pengawetan kayu, khususnya yang memiliki kelas awet rendah.

Bahan pengawet yang digunakan dalam pengawetan kayu harus bersifat racun atau repellent terhadap organisme perusak kayu. Saat ini, eksplorasi bahan pengawet yang ramah lingkungan sebagai alternatif pengganti bahan pengawet konvensional (kimia sintesis) yang tidak ramah lingkungan giat dilakukan dengan memanfaatkan bahanbahan alami seperti ekstrak dari tanaman. Senyawa aktif dari beberapa jenis tanaman telah diketahui bersifat racun terhadap organisme perusak kayu antara lain ekstrak daun kratom (Mitragyna speciosa Korth) (Rabani et al. 2017, daun mangrove (Syahidah \& Subekti 2019), daun sambiloto (Eskani et al. 2018), dan kayu ulin (Amaliyah, et al. 2019). Salah satu tumbuhan yang dapat dijadikan sebagai bahan pengawet alami adalah tanaman tuba. Ekstrak tumbuhan tuba mengandung senyawa yang disebut rotenon/tubotoxin serta senyawa lain seperti deguelin, elliptone, sumatrol dan toxicarol. Namun senyawa yang paling banyak ditemukan dan telah banyak dimanfaatkan adalah rotenon (Yoon 2006).

Keberhasilan proses pengawetan ditentukan oleh beberapa faktor, salah satunya struktur anatomi kayu seperti trakeid, pori, saluran damar, dan serat
(Muslim 2011). Pemilihan metode yang digunakan dalam proses pengawetan juga merupakan faktor yang sangat mempengaruhi efektifitas dari proses pengawetan. Metode pengawetan kayu yang sering digunakan yaitu rendaman panas dan rendaman dingin karena tergolong murah dan efektif dalam proses pengawetan kayu (Rinaldi et al. 2012, Suriani 2018, Firmanto 2017). Oleh karena itu, ekstrak daun tuba akan dikembangkan dalam penelitian ini sebagai bahan pengawet dengan menggunakan metode pengawetan rendaman panas dan rendaman dingin pada kayu agatis dan kayu kemiri.

\section{Metodologi Penelitian}

\section{Penyiapan sampel}

Daun tuba diperoleh dari Dusun Cabbengnge, Desa Tadang Palie, Kecamatan Sibulue Kabupaten Bone. Tanaman tuba diambil daunnya, dibersihkan dengan air mengalir agar kotoran hilang. Daun kemudian dikeringkan selama beberapa hari tanpa terkena sinar matahari dalam ruangan bersuhu $\pm 28{ }^{\circ} \mathrm{C}$, kemudian digiling menggunakan hammer mill (merk Retsch Muhle, Type SK1, West Germany) untuk mendapatkan serbuk dengan ukuran lolos 40 mesh dan tertahan 60 mesh.

Contoh uji dikering udarakan dalam ruangan bersuhu $\pm 28{ }^{\circ} \mathrm{C}$ dan setelah itu dibuat dengan ukuran sortimen $(5 \times 5 \times 5)$ $\mathrm{cm}^{3}$. Contoh uji setiap perlakuan sebanyak 3 kali pengulangan, sehingga total contoh uji sebanyak 18 buah (3 ulangan x 2 metode x 3 perlakuan) untuk masing-masing jenis kayu.

\section{Ekstraksi sampel bahan pengawet}

Metode ekstraksi bahan pengawet menggunakan metode maserasi, dimana sebanyak $100 \mathrm{~g}$ serbuk dimasukkan ke 
dalam gelas kimia. Serbuk kemudian diekstrak dengan pelarut etanol dengan perbandingan serbuk: etanol (1:5) selama $\pm 3 \times 24$ jam. Ekstrak kemudian disaring dan residu diekstrak lagi. Ekstraksi dihentikan bila tidak terjadi lagi perubahan warna pelarut (bening). Kemudian hasil ekstraksi divakum dengan menggunakan alat rotary vacuum evaporator. Selanjutnya dilakukan penguapan etanol dengan cara disimpan dalam desikator selama 2-3 hari. Setelah itu dibuat konsentrasi ekstrak daun tuba $2 \%, 4 \%$, dan $6 \%(\mathrm{~b} / \mathrm{v})$ dengan pelarut etanol untuk pengujian terhadap rayap. Berdasarkan hasil penelitian, konsentrasi $4 \%$ ternyata menunjukkan hasil efektif dengan mortalitas rayap lebih dari $50 \%$ sehingga konsentrasi $4 \%$ ini yang digunakan dalam pengawetan ini (Hidayatullah et al. 2017).

\section{Proses pengawetan}

Contoh uji yang sudah disiapkan dicat pada kedua bagian aksial agar bahan pengawet tidak masuk pada arah longitudinal (Sumaryanto et al. 2013, Febrianto et al. 2014). Contoh uji kemudian dikondisikan dalam suhu ruangan (kering udara) selama 2 minggu hingga beratnya konstan. Kemudian dikeringkan dalam oven dengan suhu 60 ${ }^{\circ} \mathrm{C}$ selama 48 jam. Selanjutnya contoh uji ditimbang untuk mengetahui berat awal sebelum diawetkan $\left(\mathrm{B}_{0}\right)$. Selanjutnya contoh uji disusun dalam bak perendaman, diberi pemberat dengan tujuan agar contoh uji benar-benar terendam dalam larutan bahan pengawet. Contoh uji direndam selama variasi waktu yang telah ditentukan sesuai dengan rancangan penelitian. Perlakuan dibedakan berdasarkan lama perendaman yaitu selama 3 hari, 5 hari, dan 7 hari untuk metode rendaman dingin. Sedangkan pada metode rendaman panas, lama perendaman 3 jam, 5 jam, dan 7 jam pada suhu $70{ }^{\circ} \mathrm{C}$ (Barly \& Lelana 2009).

Setelah memenuhi waktu yang ditentukan, contoh uji dikeluarkan dari bak perendaman lalu ditiriskan, kemudian dilap untuk menghilangkan sisa larutan yang berada di permukaan contoh uji, setelah itu ditimbang untuk mendapatkan berat setelah pengawetan $\left(\mathrm{B}_{1}\right)$. Tahap berikutnya dilakukan pengondisian sama seperti sebelum diawetkan yaitu contoh uji dimasukkan ke dalam oven dengan suhu $60{ }^{\circ} \mathrm{C}$ selama 48 jam kemudian dikeluarkan dari oven, hal ini dilakukan agar bahan pengawet berfiksasi dengan kayu. Kemudian ditimbang untuk memperoleh berat kering udara setelah pengawetan. Pengkondisian sampel untuk mendapatkan berat kering udara sebelum dan setelah proses pengawetan dilakukan pada kondisi suhu dan kelembaban udara yang sama. Kemudian contoh uji dibelah menjadi dua bagian untuk mengetahui penetrasi bahan pengawet.

Contoh uji yang telah diberi bahan pengawet kemudian dihaluskan pada bidang aksial. Distribusi bahan pengawet diamati dengan menggunakan mikroskop stereo.

\section{Variabel yang diukur}

Proses pengawetan kayu yang diamati yaitu retensi, penetrasi, dan distribusi bahan pengawet di dalam kayu. Berat dan volume awal dan akhir contoh uji sebelum dan sesudah proses pengawetan dilakukan untuk menghitung retensi bahan pengawet sebagaimana diuraikan Abdurrohim (1993) dengan menggunakan rumus $\mathrm{R}=\mathrm{A} / \mathrm{V} \quad \mathrm{x} \quad \mathrm{K}$; dimana $\mathrm{R}=$ retensi, $\mathrm{A}=$ Absorbsi $(\mathrm{kg})$, $\mathrm{V}=$ Volume contoh uji kayu $\left(\mathrm{m}^{3}\right)$ dan 
$\mathrm{K}=$ Konsentrasi larutan bahan pengawet yang digunakan.

Sementara itu pengukuran penetrasi dilakukan dengan cara memotong contoh uji menjadi dua. Terbentuknya warna menandakan terdapatnya bahan pengawet di dalam kayu. Tanda batas yang telah dipindahkan selanjutnya diukur kedalamannya (Gambar 1).

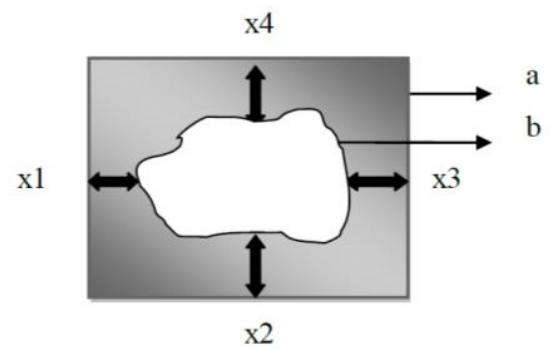

Gambar 1 Penampang contoh uji untuk pengukuran penetrasi.

dengan:

a = bagian yang ditembus bahan pengawet

b = bagian yang tidak ditembus bahan pengawet

$\mathrm{x} 1=$ penetrasi pada sisi 1

$\mathrm{x} 2=$ penetrasi pada sisi 2

$\mathrm{x} 3=$ penetrasi pada sisi 3

$\mathrm{x} 4=$ penetrasi pada sisi 4

Kemudian pada keempat sisi diukur penembusan bahan pengawet lalu nilai penetrasi (Z) dihitung dengan menggunakan rumus:

$\mathrm{Z}=\left(\mathrm{X}_{1}+\mathrm{X}_{2}+\mathrm{X}_{3}+\mathrm{X}_{4}\right) / 4$ (Barly \& Permadi 1987).

Distribusi bahan pengawet pada kayu ditentukan dengan menyayat tipis-tipis contoh uji yang telah diberi bahan pengawet menggunakan cutter tajam. Distribusi bahan pengawet dalam kayu diamati pada bidang aksial untuk melihat sebaran bahan pengawet pada masingmasing tipe sel penyusun kayu dengan menggunakan mikroskop stereo dengan perbesaran $25 \mathrm{x}$.

\section{Hasil dan Pembahasan}

\section{Pengawetan kayu}

Proses pengawetan kayu dilakukan dengan menggunakan konsentrasi ekstrak daun tuba 4\%. Hal ini didasarkan pada hasil penelitian uji rayap dimana pada konsentrasi $4 \%$, ekstrak daun tuba telah menunjukkan hasil efektif dengan mortalitas rayap lebih dari 50\%. Pada proses pengawetan kayu terdapat tiga variabel yang diamati dan diukur yaitu retensi, penetrasi dan distribusi bahan pengawet. Berikut adalah hasil yang diperoleh setelah melakukan proses pengawetan pada kayu kemiri dan kayu agatis.

\section{Retensi}

Retensi merupakan salah satu parameter keberhasilan proses pengawetan. Retensi adalah banyaknya bahan pengawet yang tertinggal di dalam kayu, dinyatakan dalam $\mathrm{kg} \mathrm{m}^{-3}$ (Djauhari 2012).

Pengawetan dengan ekstrak daun tuba menggunakan metode yang berbeda dan variasi lama perendaman pada kayu kemiri dan kayu agatis memberikan nilai retensi yang berbeda-beda, sebagaimana yang dapat dilihat pada Tabel 1.

Tabel 1 Nilai retensi bahan pengawet berdasarkan lama perendaman

\begin{tabular}{ccc}
\hline Lama perendaman & \multicolumn{2}{c}{ Retensi, $\mathrm{kg} \mathrm{m}^{-3}$} \\
\cline { 2 - 3 } & Kemiri & Agatis \\
\hline Rendaman panas & 1,7 & 2,0 \\
$\quad(3$ jam $)$ \\
$\begin{array}{c}\text { Rendaman panas } \\
\quad(5 \text { jam })\end{array}$ & 2,5 & 3,1 \\
$\begin{array}{c}\text { Rendaman panas } \\
\quad(7 \text { jam })\end{array}$ & 2,9 & 3,2 \\
$\begin{array}{c}\text { Rendaman dingin } \\
\quad(3 \text { hari) }\end{array}$ & 5,2 & 5,3 \\
$\begin{array}{c}\text { Rendaman dingin } \\
\quad(5 \text { hari })\end{array}$ & 7,2 & 7,4 \\
$\begin{array}{c}\text { Rendaman dingin } \\
(7 \text { hari })\end{array}$ & 9,2 & 9,5 \\
\hline
\end{tabular}


Berdasarkan Tabel 1 di atas tampak bahwa nilai retensi pengawet ekstrak daun tuba terbesar terjadi pada perendaman dingin dengan lama perendaman 7 hari untuk kedua jenis kayu dan nilai retensi terendah pada perlakuan perendaman air panas dengan lama perendaman 3 jam. Diketahui bahwa pada dasarnya nilai retensi akan semakin meningkat seiring pertambahan lama perendaman. Sebagaimana yang diungkapkan Suranto (2002) bahwa semakin lama jangka waktu yang diperlukan untuk merendam kayu akan membuat proses pengawetan semakin efektif. Selanjutnya, Eskani dan Utamaningrat (2019) menyatakan bahwa semakin tinggi konsentrasi bahan pengawet dan semakin lama waktu perendaman maka nilai retensi akan semakin besar. Abdurrohim dan Martawijaya (1987) menyampaikan bahwa konsentrasi larutan berpengaruh terhadap keterawetan kayu karena semakin tinggi konsentrasi larutan, umumnya makin dalam penetrasi dan makin besar retensi bahan pengawet tersebut. Bahan pengawet dengan retensi tinggi menunjukkan bahwa bahan pengawet tersebut mampu terserap ke dalam struktur kayu. Jumlah bahan pengawet yang terserap ke dalam kayu akan menentukan tingkat perlindungannya terhadap kayu dari serangan organisme perusak kayu (Vachlepi et al. 2015).

Berdasarkan hasil penelitian ini, maka dapat disimpulkan bahwa rata-rata nilai retensi yang diperoleh belum memenuhi untuk penggunaan di luar ruangan. Namun untuk penggunaan dalam ruangan perlakuan perendaman dengan lama 7 hari telah memenuhi standar. Secara umum nilai retensi bahan pengawet yang dapat diperuntukkan untuk penggunaan dalam ruangan sebesar $8 \mathrm{~kg} \mathrm{~m}^{-3}$ dan penggunaan di luar ruangan sebesar $11 \mathrm{~kg} \mathrm{~m}^{-3}$ sebagaimana yang dipersyaratkan dalam SNI 035010. 1-1999.

\section{Penetrasi}

Penetrasi adalah dalamnya penembusan bahan pengawet ke dalam kayu yang dinyatakan dalam $\mathrm{mm}$ dan berdasarkan Standar Nasional Indonesia (SNI) Pengawetan Kayu untuk Perumahan dan Gedung tahun 1999, rata-rata penetrasi yang disyaratkan adalah $5 \mathrm{~mm}$. Penetrasi dipengaruhi oleh struktur anatomi kayu dan kandungan zat ekstraktif yang mengisi pori-pori kayu yang dapat menghambat masuknya bahan pengawet ke dalam kayu (Krisdianto et al. 2015). Adapun nilai penetrasi pada penelitian ini dapat dilihat pada Tabel 2.

Tabel 2 memperlihatkan bahwa peningkatan nilai penetrasi seiring dengan semakin lamanya proses perendaman. Hal ini disebabkan oleh karena semakin lama waktu perendaman, maka semakin memberikan kesempatan pada larutan pengawet untuk masuk ke dalam sel kayu melalui dinding-dinding selnya.

Tabel 2 Nilai penetrasi bahan pengawet berdasarkan lama perendaman

\begin{tabular}{ccc}
\hline Lama perendaman & \multicolumn{2}{c}{ Penetrasi, mm } \\
\cline { 2 - 3 } & Kemiri & Agatis \\
\hline $\begin{array}{c}\text { Rendaman panas } \\
(3 \text { jam })\end{array}$ & 2,76 & 2,85 \\
$\begin{array}{c}\text { Rendaman panas } \\
\quad(5 \text { jam })\end{array}$ & 2,92 & 3,18 \\
$\begin{array}{c}\text { Rendaman panas } \\
\quad(7 \text { jam })\end{array}$ & 3,62 & 3,76 \\
$\begin{array}{c}\text { Rendaman dingin } \\
\quad(3 \text { hari })\end{array}$ & 4,28 & 4,27 \\
$\begin{array}{c}\text { Rendaman dingin } \\
\quad(5 \text { hari })\end{array}$ & 4,46 & 5,38 \\
$\begin{array}{c}\text { Rendaman dingin } \\
(7 \text { hari })\end{array}$ & 8,08 & 8,11 \\
\hline
\end{tabular}

J. Ilmu Teknol. Kayu Tropis Vol. 17 No. 2 Juli 2019 
Hasil penelitian juga menunjukkan bahwa secara umum pada lama perendaman yang sama apabila nilai retensi besar maka penetrasi juga semakin dalam. Hal ini sesuai dengan hasil penelitian Djauhari (2012) yang menunjukkan bahwa retensi berhubungan dengan penetrasi, retensi bahan pengawet yang tinggi memiliki kecendrungan penetrasi yang dalam.

Syarat penetrasi yang ditetapkan untuk penggunaan dalam ruangan dan luar ruangan yaitu sedalam $5 \mathrm{~mm}$. Dari hasil penelitian dapat diketahui bahwa nilai penetrasi ekstrak daun tuba ke dalam kayu kemiri pada lama perendaman 7 hari $(8,08 \mathrm{~mm})$ telah memenuhi standar SNI 03-5010. 1-1999. Sedangkan untuk kayu agathis pada perlakuan lama perendaman 5 hari $(5,38 \mathrm{~mm})$ dan 7 hari $(8,11 \mathrm{~mm})$ telah memenuhi standar SNI 03-5010. 1-1999.

\section{Distribusi bahan pengawet}

Pengamatan distribusi bahan pengawet pada kayu agatis dan kayu kemiri diamati pada bidang aksial kayu dengan menggunakan mikroskop stereo. Perubahan sifat mikroskopis yang terjadi pada kayu agatis dan kayu kemiri dapat dilihat pada Gambar 2. Kayu agatis sebelum diberi ekstrak daun tuba berwarna kuning kecokelatan (Gambar 2(a)), setelah diberi ekstrak daun tuba warna kayu agatis berubah menjadi warna hijau gelap (Gambar 2(b)). Hal yang sama terjadi pada kayu kemiri sebelum diberi ekstrak daun tuba berwarna keabu-abuan (Gambar 2(c)), setelah diberi ekstrak daun tuba berubah menjadi warna hijau tua (Gambar 2(d)). Perubahan warna yang terjadi kemungkinan karena ekstrak daun tuba yang mengandung senyawa rotenone masuk ke dalam kayu. Senyawa rotenone jika terbuka terhadap cahaya dan udara mengalami perubahan warna kuning terang menjadi kuning pekat, orange dan terakhir menjadi hijau tua (WHO 1992).

Keberadaan bahan pengawet pada kayu kemiri dapat terlihat pada sel parenkim kayu. Bahan pengawet yang masuk ke dalam kayu kemiri mengendap pada bagian parenkim dengan warna hijau yang gelap. Hasil yang sama didapatkan oleh Matsunaga et al. (2004) terhadap kayu yang diawetkan dengan bahan pengawet tembaga, diketahui bahwa bahan pengawet tersebut terdistribusi dalam perenkim, dinding sel, dan lamella tengah. Namun, keberadaan bahan pengawet pada kayu agatis belum dapat dilihat dengan jelas, perlu preparasi sampel yang lebih baik dan menggunakan mikroskop dengan perbesaran yang lebih tinggi.
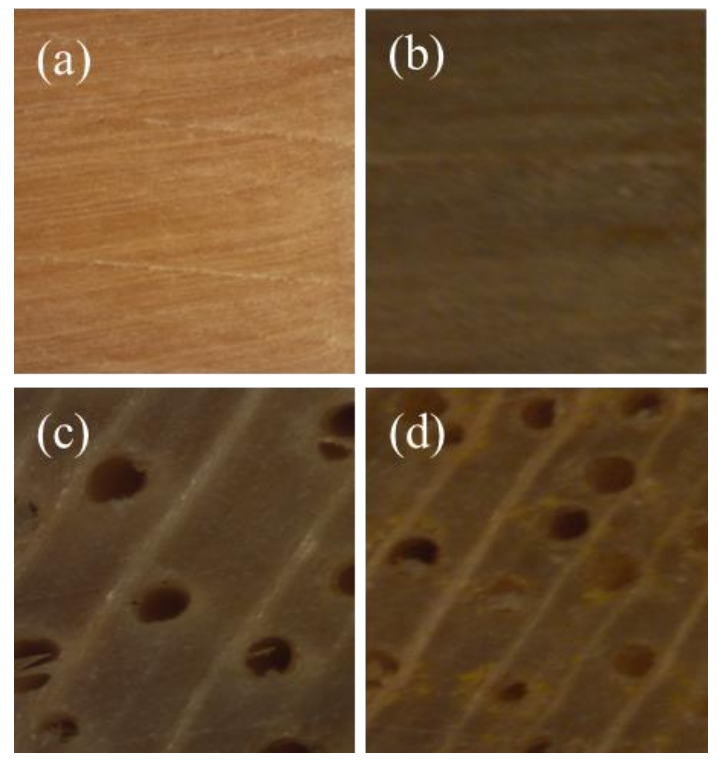

Gambar 2 Penampakan aksial kayu agatis (a) sebelum perendaman, (b) setelah perendaman dan Penampakan aksial kayu kemiri (c) sebelum perendaman, (d) setelah perendaman (perbesaran 25x). 


\section{Kesimpulan}

Berdasarkan penelitian yang telah dilakukan maka dapat disimpulkan bahwa:

1. Retensi bahan pengawet ekstrak daun tuba pada kayu kemiri sebesar 9,2 kg $\mathrm{m}^{-3}$ dan kayu agatis sebesar $9,5 \mathrm{~kg} \mathrm{~m}^{-3}$ telah memenuhi persyaratan penggunaan di dalam ruangan dengan metode rendaman dingin selama 7 hari.

2. Penetrasi pengawet ekstrak daun tuba pada kayu kemiri dengan metode rendaman dingin selama 7 hari dan kayu agatis dengan metode rendaman dingin selama 5 hari dan 7 hari telah memenuhi SNI 03-5010. 1-1999.

3. Distribusi bahan pengawet pada kayu kemiri terdapat pada sel parenkim kayu sedangkan pada kayu agatis tidak dapat dideteksi dengan menggunakan mikroskop stereo.

\section{Daftar Pustaka}

Abdurrohim S. 1993. Pengawetan lima jenis kayu secara rendaman dingin dengan dua jenis bahan pengawet CCB. JPHH. 11(7):256-266.

Abdurrohim S, Martawijaya A. 1987. Pengawetan dua puluh jenis kayu lrian Jaya secara rendaman panas- dingin. JPHH. 4(3):1-9.

Amaliyah DM, Lestari RY, Raharjo NL, Hamdi S, Cahyana BT, Nurmilatina. 2019. Efektivitas ekstrak kayu ulin (Eusideroxylon zwageri) sebagai pengawet alami kayu terhadap serangan rayap tanah (Coptotermes curvignathus Holmgren). JRIHH. 11(2):85-96.

Barly, Permadi P. 1987. Pengawetan sebelas jenis kayu dengan metode rendaman panas-dingin. JPHH. 4(4):8-14.

Barly, Lelana NE. 2009. Pengaruh ketebalan kayu, konsentrasi larutan dan lama perendaman terhadap hasil pengawetan kayu. JPHH. 28(1):1-8

Barly. 2013. Peran Pengawetan Kayu, Penelitian dan Aplikasinya, Prosiding Pertemuan Ilmiah Orasi Peneliti Utama. Eds: R. Sudradjat, G. Pari dan A. Santoso: 45 - 65.

[SNI] Standar Nasional Indonesia. 1999. Pengawetan Kayu untuk Perumahan dan Gedung. SNI 03-5010.1-1999. Jakarta: Badan Standardisasi Nasional.

Djauhari D. 2012. Pengaruh konsentrasi bahan pengawet boron terhadap retensi dan penetrasi pada kayu rakyat. [Skripsi]. Bogor: Insitut Pertanian Bogor.

Eskani IN, Utamaningrat IMA. 2019. Pengaruh konsentrasi, waktu perendaman, dan jenis kayu pada pengawetan alami kayu menggunakan ekstrak daun sambiloto. Dinamika Kerajinan dan Batik. 36(1):61-70.

Eskani IN, Utamaningrat IMA, Suheryanto D. 2019. Pengawetan alami kayu ketapang (Terminalia catappa) menggunakan ekstrak daun sambiloto (Andrographis paniculata) sebagai bahan baku untuk produk interior. Prosiding Seminar Nasional Teknik Kimia "Kejuangan”; 2018 April 12; Yogyakarta, Indonesia. Yogyakarta: Teknologi Industri UPN Veteran. hlm K3-1-K3-5.

Febrianto F, Gumilang A, Carolina A, Yoresta FS. 2014. Distribusi bahan peengawet larut air pada kayu diawetkan secara sel penuh dan sel kosong. JITKT. 12(1):20-32.

Firmanto A. 2017. Teknologi pengawetan kayu bangunan dalam rangka menambah nilai ekonomi kayu. Jurnal Logika. 19(1):12-19.

Hajra SA. Mehta, Pandey P, John J, Mehta P. 2010. Antibacterical property of crude ethanolic extract of mikania micrantha. Asian J. Exp. Biol. Sci. Spl. 2010:158160.

Hidayatullah S, Rizaldi AA, Gracia H, Syahidah. 2017. Efikasi ekstrak daun tuba

J. Ilmu Teknol. Kayu Tropis Vol. 17 No. 2 Juli 2019 
sebagai anti rayap alami. JITKT. 15 (2):167-174.

Krisdianto, Sudika DA, Wahyudi A, Muslich M. 2015. Keterawetan enam jenis kayu dari jawa barat dan riau. JPHH. 33(4): 329-336.

Matsunaga H, Matsumura J, Oda K. 2004. $\mathrm{X}$-ray microanalysis using thin sections of preservative-treated wood. Relationship of wood anatomical features to the distribution of copper. IAWA J. 25(1): 79-90.

Muslim R, 2011. Pengaruh pengawetan dengan wood injector terhadap sifat fisis dan kekuatan kayu pada kayu balsa (Ochroma Bicolor Rowlee) dan akasia (Acacia Mangium Willd.). [Skripsi] Fakultas Pertanian. Bogor: Institut Pertanian Bogor.

Vachlepi A, Suwardin D, Hanifarianty S. 2015. Pengawetan kayu karet menggunakan bahan organik dengan teknik perendaman panas. J. Penelit. Karet. 33 (1): 57-64.

Rabani, Diba F, Muflihati. 2017. Penghambatan pertumbuhan jamur schizophyllum commune fries oleh ekstrak etanol daun kratom (Mitragyna speciosa Korth). JHL. 5 (3): 831-839.

Rinaldi NA, Listyanto T, Karyanto O, Lukmandaru G. 2012. Pengawetan metode rendaman panas dingin kayu sengon dengan ekstrak buah kecubung terhadap serangan rayap kayu kering. Prosiding Seminar Nasional MAPEKI $X V ; 2012$ November 6-7; Makassar, Indonesia. Bogor: Masyarakat Peneliti Kayu Indonesia. hlm 478-484.
Sumaryanto A, Hadikusumo SA, Lukmandaru G. 2013. Pengawetan kayu gubal jati secara rendaman dingin dengan pengawet boron untuk mencegah serangan rayap kayu kering (Cryptotermes cynocephalus Light). JIK. 7(2):93-107.

Suranto S. 2002. Pengawetan Kayu: Bahan dan Metode. Yogyakarta: Kanisius

Suriani E. 2018. Kajian terhadap variasi metode dan bahan pengawet pada proses pengawetan bambu-kayu di indonesia. EMARA - Indonesian J. Architecture. 4(1): 54-64.

Syahidah, Subekti N. 2019. Biological activity of mangrove leaves extract (Rhizophora sp.). Proceeding of The $1^{\text {st }}$ Biennial Conference on Tropical Biodiversity; 2018 September 20-21; Makassar, Indonesia. IOP Conf. Series: Earth and Environmental Science. 270 (2019) 012051 doi:10.1088/17551315/270/1/012051.

Tarumingkeng RC. 1992. Insektisida: Sifat, Mekanisme Kerja dan Dampak Penggunaannya. Jakarta: Universitas Kristen Krida Wacana.

Yoon AS. 2006. Extraction of rotenone from Derris Elliptica and Derris malaccensis by pressurized liquid extraction compared with maceration. J. Cromatography A. 20(2): 172-176

[WHO] World Heath Organization. 1992. The WHO recommended classification of pesticides by hazard and guidelines to classification 1992-1993. Genewa: WHO. 